\title{
THE LEGAL HERITAGE OF PLYMOUTH COLONY *
}

\section{GEORGE L. Haskins $\dagger$}

More than one legal historian has more than once drawn attention to the contributions that Plymouth Colony made to American law in the seventeenth century. ${ }^{1}$ Yet recent general studies continue to insist that Plymouth made few permanent contributions of any kind to the American heritage. Thus, Samuel Eliot Morison, dean of American colonial historians, writes that nearly all American historians are now agreed upon "the insignificance of the Plymouth Colony in the colonial era." 2 "By any quantitative standard," he says, "it was one of the smallest, weakest, and least important of the English colonies." 3 "Massachusetts Bay, rather than Plymouth Colony, was the seed bed of New England. There and in Connecticut and New Haven the distinctive New England institutions of church and state, culture and commerce were developed." 4

To this majority opinion of the court of history these pages are filed as a partial dissent. In the light of the known evidence, it is impossible to disagree with much that Professor Morison has concluded with respect to Plymouth. The Pilgrims who founded the colony were simple folk, drawn principally from a class that, in Governor Bradford's words, "followed the inocente trade of husbandrey." 5 They had little familiarity with any intellectual currents of the day except those pertaining to religion. They were not and did not become great shipbuilders, successful fishermen, or traders. They did not establish or

* Revised and developed from an address delivered on Massachusetts Heritage Day at Plimoth Plantation, Plymouth, Massachusetts, October 21, 1961, and reproduced with permission of the sponsors. The address, as originally presented, appeared in 26 Social Education 7 (1962).

$\dagger$ A.B. 1935, LL.B. 1942, Harvard University. Professor of Law, University of Pennsylvania.

1 E.g., Goebel, King's Law and Local Custom in Seventeenth Century New England, 31 CoLum. L. Rev. 416, 448 (1931); Haskins, The Beginnings of the Recording Systen in Massachusetts, 21 B.U.I. REv. 281, 302 (1941).

2 Morrson, By Land And By Sea 234 (1953).

3 Id. at 235.

$4 I d$. at 234. Although he concedes that Plymouth instituted civil marriage, a registry of deeds, and the first Congregational Church, Morison goes on to say that even the Pilgrim church at Plymouth was soon overshadowed by the Congregational churches that sprang up elsewhere in New England and by such learned clergymen as Hooker, Cotton, and Shepard, whose counterparts could not be found at Plymouth. Id. at 235. Since the publication of Professor Morison's essay on Plymouth, op. cit. supra note 2 , he has explicitly given the colony credit for instituting the first bill of rights. Morison, THE StORY OF THE "Old ColONY" OF NEW PlyMOUTH 152-53 (1957).

5 1 Bradford, History of Plymouth Plantation 28 (1912). 
live under democracy in any modern sense. Indeed, much that they accomplished was done after annexation to Massachusetts in 1691. In large measure, their importance lies in the example they continue to afford of courage in the face of danger, resourcefulness in the face of difficulty, and fortitude in the face of adversity. ${ }^{6}$ In spiritual quality, the Pilgrim leaders were second to none in the New World, and in many respects, as Henry Adams said of the great Virginians at the close of the 18th century, they were "equal to any standard of excellence known to history. Their range was narrow, but within it they were supreme." ?

At the same time, it must be recognized that Plymouth Colony made several important contributions to American legal institutions, not the least of which was an early articulation of the ideal that finds expression in the famous language of the Constitution of Massachusetts-"a government of laws and not of men." 8 At the outset, the colonists succeeded in establishing a self-governing community without benefit of a royal charter, royal proprietor, or corporate overlord, and in this respect they evinced an early political maturity which was not matched in any other American colony. They also succeeded in establishing a system of law suited to the situation and conditions in which they found themselves and to the religious purposes for which the colony had been established.

\section{The Code of 1636}

In assessing Plymouth's contribution to the American legal heritage, it should first be pointed out that to that colony belongs the credit of having established what may fairly be described as the first American constitution. At a meeting of the General Court in October 1636, the laws of the colony were read, and some "were found worthy the reforming-others the rejecting and others fitt to be instituted and made." 9 In consequence, a committee was appointed to "sertefie and prepare such as should be thought most convenient, that if approved they may be put in force at the next general court." 10 The work was accomplished within a few weeks, and the laws were drawn up in the form of a code dated November $15,1636.11$

Two things are remarkable about this code, which turned out to be something more than a mere compilation and revision of existing

${ }^{6}$ Cf. Morison, op. cit. supra note 2, at 235.

71 Adams, History of the United States of America 133 (1889).

8 Mass. Const. art. 30.

9 The Compact With the Charter and Laws of the Colony of New Plymouta 35 (Brigham ed. 1836) [hereinafter cited as Plyadoutr Laws].

10 Ibid.

$11 \mathrm{Id}$. at 36. 
laws. In the first place, the code sets forth the general scheme or frame of government of the colony: the source of legislative power, the duties and authority of the several officers of the colony, qualifications for the franchise, provision for the holding of courts, and the source of authority to declare war. Second, it contains a rudimentary bill of rights, certainly the first in America, antedating by five years that adopted by Massachusetts Bay in the Body of Liberties of $1641 .^{12}$ These two features alone justify the statement that the 1636 code established a constitution of the type that was to become familiar in America after the Revolution. Nothing that was attempted earlier in Virginia was of the same scope; there the so-called constitution was chiefly composed of orders and instructions directed at, but not established by, the colonists, and certainly it included nothing that might be termed a general bill of rights. ${ }^{13}$

\section{Significance of the 1636 Code}

The 1636 code, with its revision of the colony's laws and enactment of constitutional provisions, is significant from four standpoints : first, because this codification-quite apart from its constitutional significance-was the first code of laws in any modern sense in North America; second, because it reveals much of the social organization of the colony; third, because it preserved and gave vitality to English legal institutions which otherwise might not have survived; fourth, because it contains laws, first introduced at Plymouth, that made lasting contributions to the present-day law of Massachusetts and, ultimately, to the modern law of the United States.

\section{A. The First Modern Code in America}

In the history of world jurisprudence, codification of law may be said to have taken two forms, roughly described by the terms "ancient" and "modern." Of the former type are the Code of Hammurabi, the Twelve Tables at Rome, and the primitive Anglo-Saxon compilations which antedate the Norman Conquest. Of the latter or "modern" type, the Code Napoléon is among the most famous. The distinction between these two types of codes is essentially that the ancient code sought to reduce traditional law to writing, often as a defense against autocratic rulers, whereas "modern" codes have had as their objectbeyond the necessary compilation-the revision of existing law in the light of accepted ideals for the purpose of elaborating the law and pro-

12 The Colonial Laws of Massachusetts 29-64 (Whitmore ed. 1889). 1933).

133 The Records of the Virginia Company of London 12-29 (Kingsbury ed. 
viding fresh starting points for legal development. ${ }^{14}$ Judged by this test, and particularly in the light of its bill of rights, the first Plymouth code is modern-not so modern as the more mature and developed code adopted by the Bay Colony in $1648,{ }^{15}$ but a first step in that direction and certainly antecedent to it. The earlier collection of Virginia laws, enacted in 1619, cannot properly be termed a code, for it manifests no effort in the direction of either revision or completeness. ${ }^{16}$ In any event, the later Plymouth revisions, embodied in compilations of 1658,1671 , and $1684,{ }^{17}$ fully justify characterization as a developed and detailed modern code. All these codes, along with that of Massachusetts Bay, provided examples that were looked to and borrowed from by other colonies in establishing their legal systems, including notably Connecticut and, later, New York under the Duke of York's laws. ${ }^{18}$

\section{B. A Sociological Document}

Although much neglected as source material, ${ }^{19}$ the Plymouth laws constitute a valuable group of contemporary documents for the understanding of Plymouth's history, and they shed important and broadly diffused light upon social, economic, and institutional developments; for, whether one looks to the 17 th or to the 20th century, law in its broad sense is much more than a complex of rules for settling disputes between litigants in court. Law is a command of the state, but it is also a social product and an agency of social control, a regime for prescribing countless aspects of the relations of men in organized society and for adjusting their desires and claims with respect to each other and to things. Although particular legal rules may be the outcome of legislation, executive order, or judicial decision, by and large those rules reflect contemporary pressures caused by the needs and interests of the community or of groups within the community. At the same time, legal rules reflect ethical elements-the sense of justice and injustice and the ideals of the society within which they operate. Hence,

14 See generally Haskins, Codification of the Law in Colonial Massachusetts: A Study in Comparative Laze, 30 Ind. L.J. 1, 2-3 (1954).

15 The Laws and Liberties of Massachusetrs (Farrand ed. 1929). Further study of the 1636 Plymouth code has led me to revise an earlier opinion, expressed in Haskins, supra note 14, at 5, that because the traditional element in the code is strong it is difficult to classify the code as "modern."

163 The Records of the Virginia Company of London 164-68, 170-74 (Kingsbury ed. 1933).

17 Plymouth Laws 105-21, 239-301.

18 Haskins \& Ewing, The Spread of Massachusetts Law in the Seventeenth Century, 106 U. PA. L. Rev. 413 (1958).

19 Although only a few copies of the collections of laws printed in 1671 and 1685 survive, these and earlier laws were published twice in the last century, in PLYMOUTH Laws and in 11 Records of the Colony of New Plymouth in New England (Pulsifer ed. 1861), and are generally available in large libraries. 
in its operation, law is both an anchor to tradition and a vehicle for change-a pressure upon social organization and a device for accommodating new and emerging forces. ${ }^{20}$

Viewed in this perspective, the legal records of Plymouth, as of any society, merit study as a reflection of social organization and social purpose. They aid in the identification of the groups-formal and informal-that make up the anatomy of social organization and in the delineation of the functions of those groups. They help us to assess, for example, the situation of debtors and creditors, the importance of the family unit, the extent to which environment affects the group and the individuals within the group. They shed light on the sentiments and understandings that make for stability or the lack of it. Hence, whether one looks to rules which prescribe that swine shall be ringed ${ }^{21}$ or to those which prescribe the economic use of land, ${ }^{22}$ the law is revealed as a highly specialized form of social control, regulating competing interests between individuals and groups in organized society.

The enacted laws also shed light on the problem of cultural transplantation to the extent that they were imitative or adoptive of those portions of the English legal system with which the colonists were familiar. At the same time, their conscious rejection of other portions of that system reflects, for example, their dissatisfaction with the English land law and with English criminal law and procedure and their urgent wish to effect reforms in those areas. Reliance upon and literal use of Biblical texts in framing provisions relating to crime provides, in another area, evidence not only of tradition and design, but of the continuing importance of the religious ideals which had inspired the founding of the colony.

The earliest Plymouth laws reflect concern about basic problems common to all communities: landholding, the inheritance of property, marriage, crime, court proceedings, and the like. As time went on and the colony grew, the laws reflected not only the maturing social organization, but local problems and conditions, such as those involved in legislation about bridges and ferries, highways, fairs, weights and measures, price and wage control, licensing of innkeepers, the quality of exports, and provision for the poor.

One of the most striking features of several provisions is the typically Puritan concern about the regulation of personal conduct and behavior. In the course of the 17 th century, Plymouth enacted numerous laws punishing and providing specified fines for drinking, gaming,

20 See Haskins, Law and Colonial Society, 9 Ax. Q. 354, 357-58 (1957).

21 Plymouth Laws 45, 58.

$22 I d$. at 47 (land to be forfeited when not occupied by grantee). 
idleness, lying, swearing, and the like. They were not general prohibitions, but for the most part detailed provisions describing the offense. The tests of drunkenness, for example, are set forth with a degree of specificity which would astound many a modern police court. ${ }^{23}$

The significance of such provisions lies not only in their exemplification of Puritan ideas about right living but in what they reveal about the Pilgrims' views of law. To them law was conceived of in large measure as a restraint on individual action in the interest of the whole group. At Plymouth, as in the Bay Colony, the individual was essentially a member of the community, so that there was no aspect of his life, not even his private conduct, which was free of the control of the law insofar as the law was designed to further effective organization and good order in the community. To us today, such intrusions upon privacy may appear as unwarranted invasions of personal liberty, but to the Puritans such regulation seemed both proper and necessary. ${ }^{24}$

Lest it be thought, however, that the legal system of Plymouth was entirely an indigenous product of local conditions and of Puritan religious beliefs, it should be emphasized that the colonists drew extensively on their English legal inheritance and even on their Dutch experience. ${ }^{25}$ There are several references to the common law of England, by which to a substantial degree they felt bound. But there are other provisions that reflect local English customs of the districts from which they had come. The terms and the forms which appear in the records are in great part the forms and procedures of manor and borough courts rather than those of the king's courts that developed the common law. ${ }^{28}$ That this should be so is not surprising, for in the 17th century the legal center of gravity for the average Englishman was the local court of the neighborhood-the borough court, the court leet, and the county court. ${ }^{27}$ There he would turn to collect a debt, replevy a cow, or abate a nuisance, and it is a matter of no small interest that the early Plymouth court records bear a striking resemblance to those of the English manorial courts of this period. ${ }^{28}$ Moreover, the code of 1636 is reminiscent of many 15 th and 16th century English borough customals, which probably furnished the models on which the colonists consciously framed this and later compilations. In

23 "And by drunkennesse is understood a person that either lisp or faulters in his speech by reason of over much drink, or that staggers in his going or that vomitts by reason of excessive drinking, or cannot follow his calling." Id. at 84.

24 See Haskins, LAw and Authority in EarLy MassachusetTs 78-80 (1960).

25 See Haskins, supra note 1 , at 289-91, where the land registration system in force in Holland during the period of the Pilgrims' sojourn at Leyden is discussed. 26 Goebel, supra note 1 , at $435-38$.

27 Id. at 420 .

28 Id. at 435 . 
them, for example, are the same recitals of authority, the specifications of power, the election of officers, the oaths to be taken, that are found in the English customals. ${ }^{29}$

\section{Preservation of English Institutions}

In adopting local customs and other practices of the borough and manor courts, the Plymouth colonists preserved and helped to transmit legal institutions which in the 17 th century still had enormous tenacity as well as vitality. In time, those customs were to be smothered by the gradual but inexorable encroachments of the common law of the king's courts. Few of the Pilgrim settlers, however, had much familiarity with that law save on the criminal side, and the customary law of the local courts assumed "a position of transcendent importance in the life of the ordinary man." 30 Hence, it was entirely natural that the colonists should have availed themselves of their cultural inheritance in customary law, just as they did in religion and methods of farming. Their introduction of a code, of a recording system, and of a scheme of partible inheritance, to give but three instances, appears to have derived in substantial measure from English customs. The idea of a code, for example, although stemming in part from the Pilgrims' reverence for the Mosaic code of the Old Testament, was well known in the English boroughs as a device which helped to assure certainty in the application and enforcement of local law and which became increasingly popular for similar purposes in the New England colonies. ${ }^{31}$ The example of the procedures of the English local courts, untechnical compared with those followed in the common-law courts, offered a flexibility that was advantageous to litigants untrained and largely unacquainted with the complexities of the forms of action. Thus, the introduction of half-remembered English customs at Plymouth brought into the stream of American law institutions which would otherwise have perished and which, instead, furnished in several areas a foundation on which that law would build. From another standpoint, those transplantations shed further light on the problem of survival and adaptation of patterns of thought and habits of life; at the same time they reflect, as in a glass darkly, much of the image of local England that was shortly to disappear from view.

\section{Substantive Provisions}

The fourth distinctive contribution of the 1636 code and of other laws which were in force but not expressly incorporated therein was in

31 See Haskins \& Ewing, supra note 18. 
the development of new laws which have since had a permanent influence on the American legal system. This contribution was in two directions.

\section{A Bill of Rights}

First, the code gave expression to the idea of fundamental law embodied in a bill of rights and written constitution. That idea had already made an appearance in Massachusetts Bay in the preceding year when it was agreed to frame a body of laws "in resemblance to a Magna Charta." 32 However, except for the draft of fundamental laws prepared in 1636 by John Cotton, which was never adopted, nothing was done about the project until the Body of Liberties was enacted in $1641 .^{33}$ Thus, the Plymouth declaration of rights, rudimentary though it was, was certainly the first enactment of its kind in America. The Preamble promptly claims for the colonists the rights and liberties of Englishmen, stating that they had come "as free borne subjects of the state of Engl. . . . endewed $\mathrm{w}^{\mathrm{ch}}$ all and singular the priviledges belong to such . . . " 34 Then, at intervals between other provisions of the code, come the following:

$[N] \circ$ imposičon law or ordnance be made or imposed upon or by ourselves or others at present or to come but such as shall be made or imposed by consent according to the free liberties of the state and Kingdome of Engl. and no otherwise. $^{35}$

That all trialls whether capitall or between man \& man be tryed by Jewryes according to the presidents of the law of Engl. as neer as may be. ${ }^{36}$

That the lawes and ordnances of the Colony \& for the government of the same be made onely by the freemen of the Corporac̃on and no other, provided that in such rates \& taxac̃ons as are or shall be laid upon the whole they be without partiality so as the freeman be not spared for his freedome, but the levy be equall. And in case any man finde himselfe aggrieved, that his complaint may be heard \& redressed if there be due cause. ${ }^{37}$

As time went on, these fundamentals were elaborated and enlarged, so that by 1671 they were expressed in much more sophisticated

321 Winthrop's Journal 151 (Hosmer ed. 1908).

33 Note 12 supra. See generally HASkINs, op. cit. supra note 24, at 124-26.

34 Plymouth Laws 36.

35 Ibid.

$36 I d$. at 42 .

37 Ibid. 
terms and in recognizably modern form, occupying nearly three full printed pages. ${ }^{38}$ It is not without interest that at least six provisions of that later code appear in equivalent form in the present-day Constitution of Massachusetts. ${ }^{39}$

\section{Innovations}

The other direction in which Plymouth made a distinctive contribution to the American legal heritage was the formulation of certain provisions of new substantive law: civil marriage, equality of descent among children, provision for widows, and recording of deeds. All these were marked advances on English law.

The introduction of civil marriage is undoubtedly the best known of Plymouth's innovations. Whereas Anglican doctrine in contemporary England, conforming to that of the Roman Catholic Church, prescribed that marriage should be solemnized in church, at Plymouth the colonists introduced marriage by officers of the civil government. Bradford speaks of the practice as having been founded on the "laudable custome of the Low-cuntries," 10 and it appears therefore to have been one of the fruits of the Pilgrims' sojourn in Holland. The practice was also followed in Massachusetts Bay when that colony was established, and its acceptance there can fairly be attributed to Plymouth influence. ${ }^{41}$ Civil marriage is not expressly dealt with in the first Plymouth code, but it appears to have been universally practiced. The general recognition of civil marriages in the United States today is too well known to require comment, but the practice can be traced at least in part to 17 th-century Plymouth.

Among the notable advances of Plymouth law over that of contemporary England was the provision for the descent of land to all children rather than to the eldest son, as under the English rule of primogeniture. $^{42}$ As early as 1627 , Isaak de Rasieres, then ActingSecretary of New Netherland, visited Plymouth and observed that "in inheritances they place all the children in one degree, only the eldest son has an acknowledgement for his seniority of birth." ${ }^{43}$ The refer-

38 Id. at 241-43.

39 Mass. Const. arts. 4, 9, 11, 12, 15, 23.

401 BradFord, op. cit. supra note 5 , at 218 .

41 Haskins, op. cit. supra note 24, at 194-95.

42 Prymouth LAws 43 . The reference to equal descent is not explicit but may be inferred from the reference to "the comendable custome of Engl. and hold of Est. Greenwich." Ibid. At the manor of East Greenwich, the Kentish custom of gavelkind was believed to be in force. Lands held in gavelkind descended to all sons. On this question, see Haskins, Gavelkind and the Charter of Massachusetts Bay, 34 Transactions Colonial Soc'x Mass. 483 (1943).

43 Letter From Isaak de Rasieres to Samuel Blommaert, in 2 N.Y. Historical Soc'y Collection, 2d Sertes 339, 352 (1849). 
ence to seniority was to the practice of giving a double portion to the eldest son, pursuant to the precept of Deuteronomy $21: 17$, upon which it was ostensibly based. The rule of partible descent was expressly recognized in 1641 in the Massachusetts Body of Liberties, which apparently adopted the Plymouth practice. ${ }^{44}$ From there it spread to Connecticut, Rhode Island, and even to Pennsylvania and thus antedated by many generations Thomas Jefferson's attack on primogeniture in 1776. In the ultimate abolition of primogeniture throughout the United States the influence of the early practice at Plymouth can hardly be ignored.

The provision for the widow was also novel. ${ }^{45}$ Generally speaking, the common law of England at this time assured a widow a life estate in one-third of all the lands of which her husband had been seised during marriage. Plymouth also recognized a similar general right, ${ }^{46}$ but went far beyond English law in assuring to her an absolute interest in one-third of his goods and chattels as well. In England, only by exceptional local custom could the widow share in personal property, as opposed to freehold lands, unless the husband left a will which expressly gave her such property. ${ }^{47}$ The Plymouth law as to personal property was also followed in Massachusetts Bay, presumptively by adoption. With modifications, it ultimately became the law of the Commonwealth. In time, the Statute of Distribution in England ${ }^{48}$ and its counterparts in America were to assure the widow of an intestate a share in her husband's personal estate, but these provisions came long after the early Plymouth law.

Of even greater significance was the introduction at Plymouth of a system of recording sales, gifts, mortgages, and other conveyances of houses and lands. ${ }^{49}$ Stemming in part from a peasant psychosis bred of years of misery brought on by the inclosure movements, yet influenced by recording practices in the English boroughs and probably by Dutch example as well, the recording system furnished basic guaran-

44 See generally Haskins, The Beginuings of Partible Inheritance in the American Colonies, 51 YALE L.J. 1280 (1942).

45 See Plymouth Laws 43.

46 Technically, dower at common law attached to all lands held in fee simple and fee tail of which the husband was solely and beneficially seised at any time during coverture and to which issue of the marriage might inherit. The Plymouth provision merely specified "a third part of his lands during her life" and therefore seems to have included lands owned by the husband at his death rather than during the marriage. In 1646 it was enacted that a wife must consent to a sale of land, so that thereafter she received some protection in lands which the husband owned and conveyed during marriage. Plymouth LAws 86 . See also Haskins, $A$ Problem in the Reception of the Common Law in the Colonial Period, 97 U. PA. L. Rev. 842 (1949).

473 Holdsworth, A History of English Law 552 (4th ed. 1936).

4822 \& 23 Car. 2 , c. 10 (1670).

49 Plymouth Laws 43. 
tees of security of land titles. As early as 1636 two features of the modern recording system were in force at Plymouth, namely, the entry of the entire deed on an official record and prior acknowledgment of the deed before a government official. These two features, subsequently adopted by Massachusetts Bay and supplemented by two further features introduced in that colony in 1640, provided the basis for modern systems not only in Massachusetts but in the United States generally. ${ }^{50}$ Indeed, it is worthy of note that, in spite of more than twelve revisions, the present-day Massachusetts recording statute ${ }^{51}$ goes back, substantially unchanged in form, to the Bay Colony act of 1640, which appears to have stemmed from the earlier enactment at Plymouth.

\section{The Rule of Law}

Each of these contributions of Plymouth-to its own laws, to the law of the Bay Colony, and, ultimately, to modern American law-is impressive. If Massachusetts Bay was to receive much of the credit as the vehicle of transmission, that fact illustrates the old saying that the Pilgrim saddle is always on the Bay horse. What is particularly impressive, however, is the evidence which appears early and persistently in the Plymouth enactments and court records, that the colonists were governed by and lived under a rule of law. ${ }^{52}$ Few ideas have had so profound or so pervasive an influence in Anglo-American jurisprudence as has the idea that no man is above the law. It has crystallized in the doctrine of the "rule" or "supremacy" of law, which has long been regarded as one of the central and most characteristic features of the Western legal tradition. The doctrine first found expression in mediaeval England in the course of struggles to check the threatened usurpations of kings. It also is evident in the numerous borough codes that expressly guarded the customs and franchises of townsfolk from the encroachments of the king's officers and the king's courts. In the 17 th century the idea rose to central prominence both as a weapon of attack upon the royal prerogative courts and as a means of protecting the established rights of individuals from the jurisdiction of such tribunals as the High Commission and the Star Chamber, which claimed not to be bound by the accepted procedures of the ordinary courts. ${ }^{53}$

The rule of law was thus much more than a doctrine of lawyers and political theorists. Few had suffered more at the hands of the

50 See generally Haskins, supra note 1.

51 Mass. Ann Laws ch. 183 (1955).

52 See generally Note, The Rule of Laze in Colonial Massachusetts, 108 U. PA. L. REv. 1001 (1960), dealing with the rule of law in the colony of Massachusetts Bay. 53 The foregoing is elaborated in Haskins, Executive Justice and the Rule of Law, 30 Speculun 529 (1955). 
prerogative courts than the Pilgrims, and all Puritans were united in a belief in the overriding force of temporal law that reflected moral law. As early as the Mayflower Compact, in 1620, the signatories covenanted and combined into a body politic and declared by virtue thereof that they did "enact, constitute and frame such just and equal laws, ordinances, acts, [and] constitutions . . . as shall be thought most meet and covenient [sic] for the general good of the colony." 54 Note that those laws, acts, and constitutions were to be "just and equal"; note, also, that the signatories themselves covenanted to give "all due submission and obedience" thereto. ${ }^{55}$ Later, in the code of 1636, the idea of a government of laws is reflected more explicitly in provisions such as that which prescribed that "no imposicon law or ordnance be made or imposed upon or by ourselves or others at present or to come but such as shall be made or imposed by consent according to the free liberties of the state and Kingdome of Engl. and no otherwise." 56 By 1671, when the Plymouth "Generall Fundamentals" had been elaborated into a recognizably modern bill of rights, it was ordered and declared in language echoing Magna Carta, and later to be repeated in so many American state constitutions:

That Justice and Right be equally and impartially Administred unto all, not sold, denied or causelesly deferred unto any.

[T] hat no person in this Government shall be endamaged in respect of Life, Limb, Liberty, Good name or Estate, under colour of Law, or countenance of Authority, but by virtue or equity of some express Law of the General Court of this Colony, the known Law of God, or the good and equitable Laws of our Nation suitable for us, being brought to Answer by due process thereof." 57

Not only the provisions of the first and later Plymouth codes, but the numerous orders, fines, and judgments recorded in the court records of the colony attest to the persistent conviction that the laws must be enforced and obeyed. The conscious adoption of laws for the expressed good of the community, together with the numerous examples of restraint on individual action, reflects an overriding concern with the interest of the order of the whole group to which the law applied. As in ancient Greece, where the promotion of good order in the community was believed to give individuals a wider freedom, so in Ply-

54 Plymouth Laws 19.

55 Ibid.

$56 I d$. at 36.

57 Id. at 241. 
mouth the community was believed to thrive on the right living of its members. Indeed, there is more than a casual relation between Plymouth ideals and the recurrent statements throughout Greek literature that to obey the law is to be free. That idea was echoed and given wide currency by Cicero, and later was reinforced by Puritan doctrine which prescribed obedience to the law as a religious duty. ${ }^{58}$ Hence it has become a priceless legacy of western civilization that we are slaves of the law as the condition of our freedom..$^{59}$

58 Figgis, The Divine Right of Kings 175 (2d ed. 1914).

59 Cicero, Oratio Pro Cluentro, c. 53 : "legum denique idcirco omnes servi sumus ut liberi esse possimus." 